\title{
Desempenho de crianças normais em testes temporais auditivos em campo livre*****
}

\author{
Performance of typical children in free field auditory temporal tests
}

\author{
Natália Barreto Frederigue-Lopes* \\ Maria Cecilia Bevilacqua** \\ Koishi Sameshima*** \\ Orozimbo Alves Costa****
}

*Fonoaudióloga. Pós-Doutoranda pelo Departamento de Fonoaudiologia da Faculdade de Odontologia de Bauru da Universidade de São Paulo (FOB USP). Bolsista de Pós-Doutorado pela Fundação de Amparo à Pesquisa do Estado de São Paulo (Fapesp). Endereço para correspondência: Rua Silvio Marchione, 3-20 - Bauru - SP CEP 17012-900 (natalia@frederigue.com.br).

**Fonoaudióloga. Professora Titular do Departamento de Fonoaudiologia da FOB - USP.

***Médico. Livre Docente. Professor Associado do Departamento de Radiologia e do Laboratório de Neurociência Cognitiva (LIM-43) da Faculdade de Medicina da USP (FMUSP).

****Médico Otologista. Professor Titular do Departamento de Fonoaudiologia da FOB - USP.

******Trabalho Realizado no Centro de Pesquisas Audiológicas do Hospital de Reabilitação de Anomalias Craniofaciais da USP - Campus Bauru.

Artigo Original de Pesquisa

Artigo Submetido a Avaliação por Pares

Conflito de Interesse: não

\section{Abstract}

Background: auditory temporal processing. Aim: to determine the performance profile of normal hearing children in temporal sequence and order detection and identification tasks in free-field. Method: forty three children with ages raging from 7 to 11 years and 5 months were evaluated in two behavioral tests - frequency patterns test (FPT) and duration patterns test (DPT) - child's version by Auditec. Both tests were applied at 60 dBNA in free-field. Children were requested to provide two types of answers: nonverbal (NV) being murmuring for FPT and manual for DPT, and verbal (V), nomination for TPF and TPD. For both tests (FPT and DPT), ten repetitions of six sequence patterns totalizing 60 stimuli were presented to each child. Results: the performance on FPT with a non-verbal response was significantly better when compared to V response for all of the subjects. Significant performance improvements with age were observed in VFPT, NVDPT and VDPT. The performance on FPT was better than the performance on PDT. The results of this study showed similar performance on temporal sequence and order detection and identification tasks when compared to other studies conducted with Brazilian population in which these tasks were applied with supra-aural earphones. Conclusion: the values obtained for FPT and DPT can be considered the parameter of normal performance for Auditec's child version in free-field for children with ages between 7 to 11 years and 5 month.

Key Words: Hearing; Auditory Perception; Children.

\section{Resumo}

Tema: processamento temporal auditivo. Objetivo: determinar o perfil de desempenho de crianças com audição normal nas tarefas de detecção e identificação da ordem e seqüência temporal em campo livre. Método: avaliou-se 43 crianças com idade entre 7 anos e 11 anos e 5 meses em dois testes comportamentais - Teste de Padrões de Frequiência (TPF) e Teste de Padrões de Duração (TPD) - versão infantil da Auditec. Os testes foram aplicados em campo livre a 60 dBNA. Foram solicitados dois tipos de respostas: não verbal (NV) sendo o murmúrio para o TPF e manual para o TPD, e verbal (V), nomeação pra TPF e TPD. Para ambos os testes (TPF e TPD) foram apresentadas 10 repetições dos 6 padrões seqüenciais, totalizando 60 estímulos para cada criança. Resultados: o desempenho no TPF com resposta NV foi significativamente superior à resposta $\mathrm{V}$ para todos os sujeitos. Constatou-se melhora significativa do desempenho com a idade para o TPFV, TPDNV e TPDV. O desempenho no TPF foi superior ao TPD. Os resultados deste estudo demonstraram semelhante desempenho nas tarefas de detecção e identificação da ordem e seqüência temporal quando comparados com outros estudos realizados na população brasileira, nos quais estas tarefas foram aplicadas com fones supra-aurais. Conclusão: os valores obtidos para o TPF e TPD podem ser considerados como referência de normalidade para a versão infantil da Auditec em campo livre em crianças de 7 anos a 11 anos e 5 meses.

Palavras-Chave: Audição; Percepção Auditiva; Criança. 


\section{Introduction}

The auditory system is sensitive to time differences of acoustic stimuli. Much of the auditory tasks involve detection, recognition, discrimination, retention and rescue of order and temporal sequence of information. Temporal processing is considered a fundamental skill in auditory perception of verbal and non-verbal sounds1, in perception of music, rhythm, and discrimination of pitch, duration and phonemes2,3,4,5.

Among the several procedures to assess temporal processing are the or Pitch Pattern Sequence Test (PPST) and the Duration Pattern Sequence Test (DPST)6,7. Both of these tests consist in the presentation of a sequence of tones that respectively differ in frequency and duration8,9. Studies that presented PPST and DPST normality scores with supra-aural phones have suggested that such tests can be technically performed in freefield because no statistically significant difference was found between the ears9,10,11,12,13,14,15,16,17,18,19.

The purpose of this study was to evaluate the performance of children with normal hearing in the tasks of detection and identification of order and temporal sequence (PPST and DPST) in free-field. The following aspects were analyzed: performance according to the type of response (non-verbal and verbal); performance according to age, related to different types of responses and performance in each test.

\section{Method}

This study was conducted at the Audiological Research Center - University of Sao Paulo - Bauru - Sao Paulo - Brazil. The study was approved by the Ethics in Human Research Committee under protocol number 152/2004-UEP-CEP. Parents or legal guardians of all study participants signed a consent form after receiving information about the objectives, rationale and methodology of the proposed study.

\section{Subjects}

Subjects were recruited from a public school in the southern area of the city of Bauru by a letter of invitation. Of the 375 letters delivered, 178 returned with approval for the study.

Inclusion criteria for the study were the following: basic audiological evaluation and completion, by parents, of the informative questionnaire20. The questionnaire addressed data on personal and family background, as well as general and linguistic development of subjects.

The basic audiological evaluation consisted of: inspection of the external ear, pure tone audiometry, speech reception threshold (SRT), speech recognition scores and acoustic impedance and acoustic reflex research. For this evaluation, an otoscope from Heine, a Midimate 622-Madsen Eletronics audiometer, TDH 39-P phones, sound attenuating booth, and AZ-7 immittance meter from Interacoustic were used. The subjects included in the study presented pure tone thresholds on measured frequencies $(250 \mathrm{~Hz}$ to $8000 \mathrm{~Hz})$ at 15dBNA or less21, consistent with SRT and speech recognition scores equal to or greater than $92 \% 22$, tympanometric curve type $\mathrm{A}$ and the presence of acoustic reflex23.

According to information obtained through the questionnaire and the data of the audiological evaluation, the subjects included in this study had the following characteristics:

. Age between seven years and 11 years and 11 months: stipulated based on normative study of Balen (2001)20 . Right manual-writting preference . No otological history

. No psychomotor and language development delay . No musical knowledge

. No hyperactive behavior and/or inattention

. No school problems.

Among the 178 subjects recruited, 43 completed all the evaluation phases, 95 were excluded by at least one of the criteria, 23 withdrew from participating in the study, 15 did not attend the scheduled pre-assessments, and nine dropped out of participating, even after the initial assessments and the PPST were carried out.

Thus, the final sample consisted of 43 subjects, 15 male and 28 female.

Procedures

The research protocol was composed of two behavioral tests: Pitch Pattern Sequence Test (PPST) and Duration Pattern Sequence Test (DPST).

The tests were conducted in free field. The intensity levels of the acoustic stimuli presented was measured using the sound level meter model 2236 from Brüel \& Kjaer. The test environment was previously prepared and calibrated. The stimulation levels that arrived to the subjects was measured with the response scale of the sound level meter. The subjects were positioned at $100 \mathrm{~cm}$ from the speaker and at $0^{\circ}$ azimuth.

The PPST and DPST were presented at a fixed intensity level of $60 \mathrm{~dB} \mathrm{HL}$, according to the 
standardization of studies conducted in the Audiological Research Center.

For both tests, we used the child version of Auditec10. The digital compact disc (CD) containing the test was connected to the Midimate 622-Madsen Electronics audiometer through the Teac PD-P30Compact Disc Digital Audio player equipment. Calibration of the CD playback was performed using the track record of pure tone $(1000 \mathrm{~Hz}$ at $60 \mathrm{~dB})$ by adjusting the visual VU meter.

The tests were applied on different days in order to avoid fatigue of the subjects and in the same order for all subjects - starting with PPST and then DPST.

PPST: presentation of 60 random sequences for each type of response adopted: nonverbal (NV) and verbal (V). The first required response was the murmur of the sequence heard (NV). Following, subjects were asked to verbally respond to the sequence heard by using the word "fine" or "high" for the high pitch and "thick" or "low" to the low pitch. The performance of each subject in the PPST was computed by the accuracy on each type of response, which was represented in percentages.

DPST: presentation of 60 random sequences for each type of response requested: NV (visual/manual) and V. In NV response, subjects had to point to a long bar to the long auditory stimuli and to a short bar to the short auditory stimuli. For the V response type, the subjects should verbally respond to the sequence heard, using the terms "long" or "large" to long stimuli and "short" or "small" to short stimuli. The performance of each subject in the PPST was computed by the number of correct answers for each type of response, which was represented in percentages.

Practice trials were conducted for all subjects in both tests. Reversals, omissions and insertion of tones and sequential patterns were considered erros12.

\section{Statistical Analysis}

The nonparametric Wilcoxon test was used to compare the performance between the two types of responses in the PPST and DPST, and to verify the possible differences in performance between both tests. The CD Pacotico, version 2.30, was used on the analysis24.
The analysis of the relationship between age and performance on the PPST and DPST were performed by the CORR procedure (used to obtain and test the correlations) of the statistical program "SAS" (Statistical Analysis System) version 8.2. The Spearman correlation coefficient was calculated. In all tests, the level of rejection of the null hypothesis was $5 \%(\mathrm{p}<0.05)$.

\section{Results}

The sample was divided according to age for the data distribution:

Group 1 - subjects between seven and nine years of age $(n=23)$

Group 2 - subjects between nine years and one month and subjects with 12 years of age $(n=20)$

Possible performance differences in the types of responses (NV and $\mathrm{V}$ ) in the PPST and DPST were analyzed using the Wilcoxon test for both groups. Statistically significant differences were found for the PPST in both groups, with better performance for NV response in comparison to $\mathrm{V}$ response. For the DPST, no significant differences in performance regarding the type of response were obtained for either group. Table 1 shows the mean, standard deviation, minimum and maximum values for each type of response in both tests, as well as the $\mathrm{p}$ values obtained in the statistical analysis.

The results of performance based on age displayed in Figures 1A (PPST) and 1B (DPST) revealed statistically significant differences for both tests and types of responses, except for PPSTNV $(p=0.8027)$. Data for age are expressed in months. The " $n$ " expressed in Figures $1 \mathrm{~A}$ and $1 \mathrm{~B}$ refers to all children evaluated $(n=43)$.

The comparison of performance between PPST and DPST (Table 2) revealed a statistically significant difference for the two types of responses evaluated in both groups. Table 2 presents mean, standard deviation, minimum and maximum values in both tests at different types of response as well as the $\mathrm{p}$ values obtained on statistical analysis. 
TABLE 1. Mean, standard deviation (SD), minimum, maximum values of performance and p values obtained in the PPST and DPST for the different types of response of Groups 1 and 2.

\begin{tabular}{|c|c|c|c|c|c|c|c|c|}
\hline & & \multicolumn{3}{|c|}{ NÃO VERBAL } & \multicolumn{2}{|c|}{ VERBAL } & \multirow[b]{2}{*}{ Maximum } & \multirow[b]{2}{*}{$p$ value } \\
\hline & & Mean $\pm d p$ & Minimum & Maximum & Mean $\pm d p$ & Minimum & & \\
\hline \multirow{2}{*}{ Group 1} & PPST (\%) & $94,3 \pm 8,4$ & 71,6 & 100 & $81,1 \pm 14,0$ & 58,3 & 100 & $0,0001^{*}$ \\
\hline & DPST (\%) & $49,6 \pm 19,6$ & 16,6 & 88,3 & $46,2 \pm 17,8$ & 21,6 & 80,0 & 0,2046 \\
\hline \multirow{2}{*}{ Group 2} & PPST (\%) & $91,4 \pm 11,2$ & 56,6 & 100 & $85,4 \pm 15,8$ & 38,3 & 100 & $0,0491^{*}$ \\
\hline & DPST (\%) & $65,8 \pm 16,2$ & 33,3 & 100 & $66,4 \pm 19,4$ & 30,0 & 91,6 & 0,5747 \\
\hline
\end{tabular}

FIGURE 1A. Correlation between performance on PPSTNV and PPSTV and age. FIGURE 1B. Correlation between performance on DPSTNV and DPSTV and age.

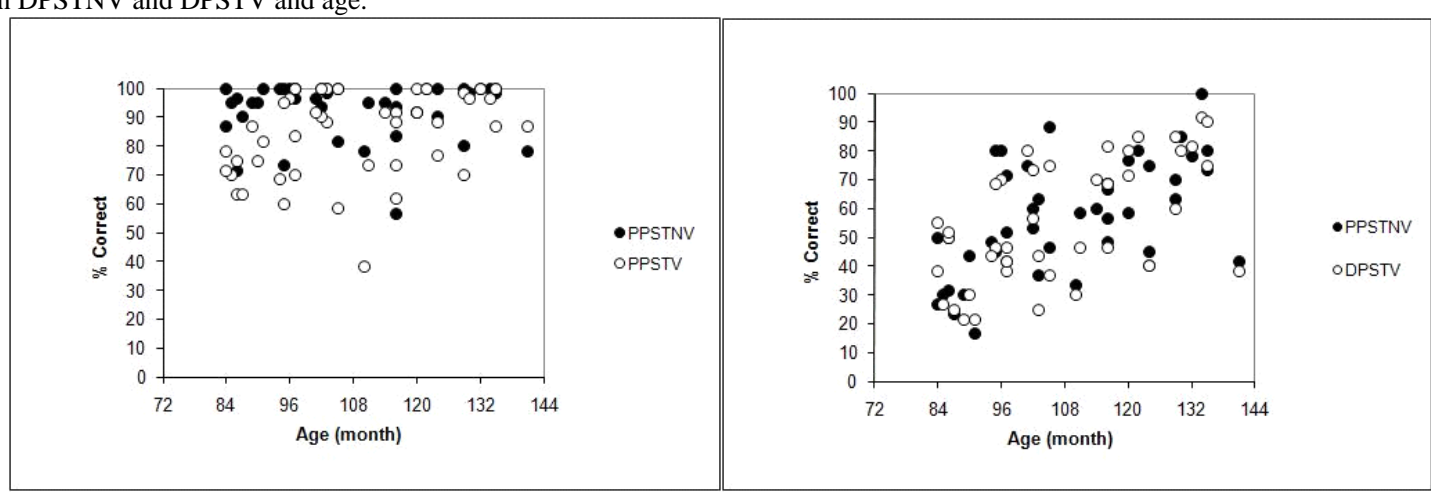

$1 \mathrm{~A}$

$1 \mathrm{~B}$

TABLE 2. Mean, standard deviation (SD), minimum, maximum values of performance and p values obtained in the PPST and DPST for the different types of response of Groups 1 and 2.

\begin{tabular}{|c|c|c|c|c|c|c|c|c|}
\hline & & \multicolumn{3}{|c|}{ PPST } & \multicolumn{2}{|c|}{ DPST } & \multirow[b]{2}{*}{ Maximum } & \multirow[b]{2}{*}{$p$ value } \\
\hline & & Mean \pm dp & Minimum & Maximum & Mean \pm dp & Minimum & & \\
\hline \multirow{2}{*}{ Group 1} & NV (\%) & $94,3 \pm 8,4$ & 71,6 & 100 & $49,6 \pm 19,6$ & 16,6 & 88,3 & $0,00002 *$ \\
\hline & V (\%) & $81,1 \pm 14,0$ & 58,3 & 100 & $46,2 \pm 17,8$ & 21,6 & 80,0 & $0,00002 *$ \\
\hline \multirow{2}{*}{ Group 2} & NV (\%) & $91,4 \pm 11,2$ & 56,6 & 100 & $65,8 \pm 16,2$ & 33,3 & 100 & $0,0001^{*}$ \\
\hline & V (\%) & $85,4 \pm 15,8$ & 38,3 & 100 & $66,4 \pm 19,4$ & 30,0 & 91,6 & $0,0005 *$ \\
\hline
\end{tabular}

* Statistically significant difference

\section{Discussion}

The purpose of this study was to establish the performance profile of normal-hearing children in free field PPST and DPST. Although there is recommendation for the application of 40 sequences in free field14, the application of the 60 available sequences was chosen in the current study so that all combinations of patterns of tones were presented. However, the tests have long duration (11min20s - PPST; and 8min16s - TPD) and some children reported fatigue after 40 stimuli. At this point, a break was provided and children were oriented that the test was almost ending. All children completed the 60 sequences. According to this finding, we recommend the implementation of the first 40 sequences in the free field.

Among the studied variables, the type of response presented results that evidenced significantly higher performance for PPSTNV in both groups. Better results for the murmured responses are also verified in the literature for normal hearing children children11,16,20.

The finding of better performance in PPSTNV demonstrates the ease in detection, recognition and 
retention of frequency patterns related to the murmur emission. The murmur does not involve memory, discrimination, and awareness of the sound sequence and it is characterized by an imitative activity, apparently with minor complexity25. The ability to recognize frequency patterns for NV response was acquired, or is present, before the age of seven and remained stable after this period20. This may indicate that the processing mechanisms of these patterns are innately present in the neuroanatomical substrate of children with typical development1,5. The task with verbal response is more complex, indicating the need for learning or neuromaturation of the nervous system. The naming task, as a linguistic activity, demands for processes with greater connections between thought and language.

In this study, there was no statistically significant difference between the types of responses for DPST. These data are consistent with another study11. However, the current results differ from Balen (2001) 20 , who found significantly higher performance only for the manual response in the left ear. The findings of the current study confirm the hypothesis that, for the DPST, both types of responses are highly elaborate. This is true because they involve cognitive functions of memory and attention, which causes great variability in performance among subjects as such skills are not acquired evenly throughout the development26,27.

The results of the PPPST observed here, according to the different ages tested, showed similarities on the performance of children in the same age group as reported in the literature11,12,16,20. In contrast, regarding the NV response type, the results were lower when compared to another study18. However, the authors of that study used a version with different acoustic characteristics and manual response, which can be as difficult as naming once it requires other mechanisms and cognitive processes.

In relation to DPST, the results corroborate with those described in literature16,17,20. However, the current results differ from results of studies carried out with adults7,12. The findings of Schochat, Sanfins and Rabelo (2000)18 illustrated results with lower performance of participants. This possibly occurred due to the use of a different version of the test.

This fact can be explained by Murphy and Schochat (2007)28 who compared the performance of children in auditory temporal processing tests according to different temporal paradigms. The authors concluded being necessary a greater focus on the time parameters in each test as these have a direct influence on performance.
Schochat, Rabelo e Sanfins (2000)18 used the version of Audiology Illustrated, which contains smaller inter-stimulus intervals. The parameters in this version hamper conduction of the test28.

Regarding the age variable, the findings obtained here support the hypothesis that performance on tasks of temporal order and sequence is influenced by age $1,15,17,18,20,26,27$. Studies that analyzed the performance of normal hearing children in the PPST and DPST report evident quantitative improvement in responses with increasing age, especially between eight and ten years2,18,29.

For the performance variable, the results showed that there are different mechanisms in the acquisition and development of skills of frequency and duration recognition patterns20 since both groups achieved superior performance in PPST. Barreiro (2003)11 did not directly compare the performance between both tests, but reports the existence of differences between them.

\section{Conclusions}

After applying the PPST and DPST in normal hearing children in free field, it was concluded that:

. in the frequency pattern test, the performance of subjects was significantly higher with non-verbal response (murmur) as compared to the verbal response (naming) for both groups;

. in the frequency pattern test, a significant improvement in performance with age increase for PPSTV was observed;

in the duration pattern test, there was progression of performance with age increase for both types of responses;

. the performance of subjects in the PPST was significantly superior to that in the DPST in all evaluation situations for both groups.

These findings suggest that, for the PPST and DPST version used, the values obtained in each test for the NV and V response types can be used as reference for children from seven years to 11 years and five months of age in free field. This may contribute to clinical routine and research involving temporal auditory tests in hearing impaired individuals who use electronic devices, as well as for conditions where the use of supra-aural earphone is not indicated. 


\section{References}

1. Bellis TJ. Assessment and management of central auditory processing disorders in the educational setting from science to practice. $2^{\mathrm{a}}$ ed. New York: Thomson Delmar Learning; 2003.

2. Phillips DP. Central auditory system and central auditory processing disorders: some conceptual issues. Semin Hear. 2002;23:251-61.

3. Domitz DM, Schow RL. A new CAPD battery - multiple auditory assessment: factor analysis and comparisons with SCAN. Am J Audiol. 2000 Dec;9(2):101-11.

4. Shin JB. Temporal processing: the basics. Hear J. 2003;56(7).

5. Musiek FE, Oxholm VB. Anatomy and phisiology of the central auditory nervous system: a clinical perspective. In: Roeser RJ, Valente M, Hosford-Dunn H. Audiology: diagnosis. New York: Thieme Medical; 2000. p. 45-72.

6. Pinheiro ML. Auditory pattern reversal in auditory perception in patients with left and right hemisphere lesions. Ohio J Speech Hear. 1976;12:9-20.

7. Baran JA et al. Auditory duration pattern sequences in the assessment of CANS pathology. ASHA. 1987;29:125.

8. Emanuel DC. The auditory processing battery: survey of common practices. J Am Acad Audiol. 2002 Feb;13(2): 93117.

9. Baran JA, Musiek FE. Avaliação comportamental do sistema nervoso central. In: Musiek FE, Rintelmann WF Perspectivas atuais em avaliação auditiva. São Paulo: Manole; 2001. p. 371-409.

10. Auditec. Evaluation manual of pitch pattern sequence and duration pattern sequence. St. Louis: Auditec; 1997.

11. Barreiro FCAB. Estudo do processamento auditivo temporal em alunos de escola pública com e sem dificuldade de leitura [tese]. São Paulo: Universidade de São Paulo; 2003.

12. Musiek FE. Frequency (pitch) and duration pattern tests. J Am Acad Audiol. 1994 Jul;5(4):265-68.

13. Musiek FE. Central auditory tests. Scand Audiol. 1999;28 (Suppl 51):33-46.

14. Musiek FE. The frequency pattern test: a guide. Hear J. 2002 Jun;55(6):58.

15. Pinheiro ML, Musiek FE. Sequencing and temporal ordering in the auditory system. Baltimore: Williams Williams; 1985. Assessment of central auditory dysfunction: foudantions and clinical correlates. 219-38.
16. Roggia SM. O processamento temporal em crianças com distúrbio fonológico [tese]. São Paulo: Universidade de São Paulo; 2003.

17. Schochat E. Desenvolvimento e maturação do sistema nervoso auditivo central em indivíduos de 7 a 16 anos de idade [tese]. São Paulo: Universidade de São Paulo; 2001.

18. Schochat E, Rabelo CM, Sanfins MD. Processamento auditivo central: testes tonais de frequência e de duração em indivíduos normais de 7 a 16 anos de idade. Pro-Fono. 2000;12(2):2-7.

19. Campos P et al. Habilidades de ordenação temporal em usuários de implante coclear multicanal. Rev Bras Otorrinolaringol. 2008 Nov Dec;74(6):884-9.

20. Balen SA. Reconhecimento de padrões auditivos de frequência e de duração: desempenho de crianças escolares de 7 a 11 anos [tese]. São Paulo: Universidade de São Paulo; 2001.

21. Silman S, Silverman CA. Auditory diagnosis: principles and applications. San Diego: Singular; 1997. Basic audiologic testing;10-67.

22. Redondo MC, Lopes OCF. In: Lopes OCF. Tratado de Fonoaudiologia. São Paulo: Roca;1997.

23. Jerger J. Clinical experience with impedance audiometry. Arch Otolaryngol. 1970 Oct;92(4):311-24.

24. Lopes ES. Pacotico, versão 2.30: pacotinho estatístico [CD-ROM]. Bauru: Faculdade de Odontologia de Bauru, Universidade de São Paulo; 2001.

25. Musiek FE, Pinheiro ML, Wilson DH. Auditory pattern perception in "split brain" patients. Arch Otolaryngol. 1980;106(10):610-12.

26. Irwin RJ et al. The development of auditory temporal acuity in children. Child Dev. 1985 Jun;56(3):614-20.

27. Jutras B, Gagne JP. Auditory sequential organization among children with and without a hearing loss. J Speech Lang Hear Res. 1999 Jun;42(3):553-67.

28. Murphy CFB, Schochat E. Influência de paradigmas temporais em testes de processamento temporal auditivo. Pro Fono. 2007 Jul-Set;19(3):259-66.

29. Chermak GD, Musiek FE. Managing central auditory processing disorders in children and youth. Am J Audiol. 1992 July;1(3):61-6. 